УДК 631.432 .24

(C) 2016 Скрипніченко С. В., кандидат сільськогосподарських наук,
Скиба Г. В., кандидат технічних наук

Житомирський державний технологічний університет

\title{
ЗМІНА ВОДНО-ФІЗИЧНИХ ВЛАСТИВОСТЕЙ ОСУШУВАНИХ ТОРФОВИХ ГРУНТІВ ПІД ВПЛИВОМ АНТРОПОГЕННИХ ФАКТОРІВ
}

\section{Рецензент - кандидат сільськогосподарських наук І. В. Давидова}

Проаналізовано процес трансформації у динаміці водно-фізичних показників осушуваних торфових трунтів під впливом довготривалого інтенсивного сільськогосподарського використання. Зміна параметрів будови торфового трунту визначає спрямованість еволючійного процесу в динаміці водно-фізичних констант. Найбільш ефективні параметри будови торфового трунту та водно-фізичні властивості формуються у разі впровадження монокультури багаторічних трав, трав'яно-просапних та зерно-трав'янопросапних сівозмін. Складність рачіонального використання осушуваних торфових трунтів в переведенні їх потенційної родючості в ефективну.

Ключові слова: водно-фізичні константи, екологічно-безпечні заходи, сівозміни, торфові трунти.

Постановка проблеми. Структура земельного фонду Землі постійно змінюється. Впродовж тисячоліть людство веде вперту боротьбу за розширення земель, придатних для сільськогосподарського використання, але недостатня увага приділяється збереженню грунтів $[4,6]$.

Агромеліоративна наука має вже досить багато даних про зміну водно-фізичних властивостей торфового грунту під впливом різного напряму його використання. Необхідних експериментальних досліджень, які б показували зміну цих властивостей під впливом відповідних заходів або інтенсивності сільськогосподарського використання осушуваних торфових грунтів, особливо в багаторічному циклі досліджень, украй мало. Тому вирішення цієї проблеми на сучасному етапі є актуальним [1].

Аналіз останніх досліджень і публікацій, у яких започатковано розв'язання проблеми. Раціональне використання осушуваних торфових грунтів зумовлює необхідність вивчення їхніх різноманітних властивостей $[2,3,5]$. Оцінка ефективності того чи іншого напряму сільськогосподарського використання торфового грунту не може обмежуватись показниками однієї продуктивності. Введення цих грунтів в інтенсивне використання призводить до корінних змін у грунтовому профілі, створення нового грунту із принциповими відмінностями за своїми властивостями від вихідного стану. Тому поставлені завдання досліджень характерні і закономірні.

Мета дослідження - дати оцінку трансформації водно-фізичних властивостей осушуваних торфових грунтів у процесі інтенсивного сільськогосподарського використання.

Завдання дослідження - встановити закономірності змін водно-фізичних констант 3 метою впровадження заходів раціонального та ефективного використання осушуваних торфових грунтів.

Методика досліджень. Об'єктом досліджень $\epsilon$ процес змін водно-фізичних констант грунту під впливом осушення та інтенсивного сільськогосподарського використання. Дослідження проводились по загальноприйнятим методикам, використовуючи матеріали аналізу багаторічних спостережень 3 метою вирішення поставлених завдань для вирішення проблеми.

Результати досліджень. Результати багаторічних наукових досліджень, проведених в умовах Західного Полісся України (м. Сарни, Рівненська обл.) на осушуваних торфових грунтах, дали змогу виявити, що з 1958 року по 2004 рік щільність його твердої фази зросла в шарі 0-30 см у

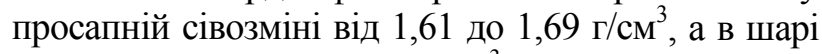
$30-50 \mathrm{~cm}-31,55$ до 1,61 г/ $\mathrm{cm}^{3}$.

Помітно збільшилася щільність твердої фази торфу і в сівозмінах 3 4-річним лучним періодом: у шарі 0-30 см - від 1,60 до $1,68 \mathrm{\Gamma} / \mathrm{cm}^{3}$, у шарі $30-50 \mathrm{~cm}-$ від 1,56 до $1,60 \mathrm{r} / \mathrm{cm}^{3}$. Також спостерігається збільшення щільності і в сівозмінах з 6-річним лучним періодом: у шарі 0-30 cм - від 1,61 до $1,67 \mathrm{r} / \mathrm{cm}^{3}$, у шарі $30-50 \mathrm{~cm}-$ від

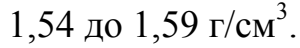

Під довготривалими луками щільність твердої фази залишилась без змін. Це пояснюється слабкою мінералізацією торфу і накопиченням у грунті органічної речовини у вигляді кореневих та поживних решток.

Оцінка ефективності того чи іншого напряму сільськогосподарського використання торфового 


\section{СІЛЬСЬКЕ ГОСПОДАРСТВО. РОСЛИННИЦТВО}

грунту не може обмежуватись показниками однієї продуктивності. Введення цих грунтів в інтенсивне сільськогосподарське використання призводить до корінних змін у грунтовому профілі, створенню нового грунту із принциповими відмінностями за своїми властивостями та будовою вихідного стану.

Встановлено, що зміна показників родючості торфового грунту обумовлюється в основному нормою осушення, видом сільськогосподарської культури, структурою посівів та чергуванням культур у сівозміні, однак параметри агрофізичних показників окультуреності грунту, зокрема $\mathrm{i}$ водно-фізичних констант, обгрунтовані у значно меншій мірі, в порівнянні з агрохімічними показниками.

Певною мірою це пояснюється 3 одного боку недосконалістю методик та методів інструментального контролю за їх зміною, 3 іншого - незначними змінами фізичних параметрів грунту в часі, що потребує досить тривалих (десятки років) польових досліджень.

Серед агрофізичних показників окультуреності грунту поряд із пористістю та щільністю виступають водно-фізичні константи: повна вологоємність (ПВ), гранична польова вологоємність (ГПВ), вологість розриву капілярного зв'язку (ВРК), вологість стійкого в'янення (ВСВ) та максимальна гігроскопічна вологоємність (МГВ). Наведені водно-фізичні константи відображають як кількісний ступінь зволоження грунту, так i якісну характеристику вологи по відношенню іiі рухомості й доступності рослинам як легкодоступну, доступну, важкодоступну, непродуктивну і недоступну.

Незначне підвищення щільності 0-30 см шару торфу в разі беззмінного посіву трав, із одночасним розширенням площ під просапними культурами, супроводжувалось істотним зниженням повної вологоємності та загальної пористості. Найбільш глибокі еволюційні процеси в цьому напрямі відбулись у варіанті під просапною сівозміною, де зниження цих показників у 0-50 см шарі за досліджуваний період становило відповідно $40 \%$ та $6 \%$.

Зміна параметрів будови торфового грунту визначала спрямованість еволюційного процесу в динаміці водно-фізичних констант. Серед інших виняткове значення у вологозабезпеченості культур відіграють ГПВ та ВРК, які характеризують верхню та нижню границі оптимального зволоження грунту.

Встановлено, що найбільш оптимальні умови водно-повітряного режиму формуються в тор- фовому грунті, гранична польова вологоємність якого становить близько 80 \% від повної вологоємності, вологість розриву капілярного зв'язку максимально наближена до вологості стійкого в'янення, яка слугує граничним показником доступності вологи для рослин.

Так, за 46-річний період найбільш інтенсивного використання грунту ГПВ 0-50 см шару знижувалась, у порівнянні із монокультурою багаторічних трав на 7,9 \%; ВРК, ВСВ та МГВ - відповідно на 2,4, 4,0 і 1,1\% (табл. 1).

Як бачимо $з$ наведених даних, найбільш оптимальні значення ГПВ та ВРК створювались під монокультурою багаторічних трав та в сівозмінах, питома вага трав у яких становить 56 \% i більше. Решта площі в таких сівозмінах відводиться під зернові культури, одне поле - під просапні.

Зменшення питомої ваги в сівозміні під багаторічними травами, а особливо їх повна заміна зерновими та просапними культурами, призводило до зниження параметрів водно-фізичних констант як в орному, так і в підорному горизонтах. Найбільш помітні еволюційні процеси в цьому напрямі мали місце в разі використання торфового грунту виключно під просапні культури.

Тривалий період інтенсивного використання торфового грунту призводить до зниження його водоакумулюючої здатності, що пов'язано 3 icтотними змінами в будові грунту.

Аналізуючи результати проведених досліджень, слід відзначити, що зі збільшенням в сівозмінах питомої ваги багаторічних трав зростають всі водно-фізичні константи (в \% на сухий грунт) як в орних, так і в підорних шарах. Найнижчий показник потенційної водомісткості (376 мм) 0-50 см шару мав місце під час впровадження просапної сівозміни (табл. 2).

Введення у структуру посівів зернових культур (до $44 \%$ ) та багаторічних трав (більше $56 \%$ ), за рахунок зменшення площ під просапними, забезпечувало не тільки підвищення водоакумулюючої здатності грунту (до 433 мм за 100 \% багаторічних трав), а й найбільш високий вміст у ньому доступної, зокрема і легкодоступної, оптимальної для засвоєння рослинами вологи (відповідно до 407 і 182 мм).

Водночас важливо зазначити, що на вказаних варіантах вміст оптимальної для рослин вологи у \% від доступної був також найвищим і становив від 34,9 до 35,1 \%, що має виняткове значення у вологозабезпеченні культур. 


\section{1. Параметри водно-фізичних констант торфового грунту} після 46-річного періоду використання, \% від ПВ

\begin{tabular}{|c|c|c|c|c|c|c|c|}
\hline \multirow[b]{2}{*}{  } & \multirow[b]{2}{*}{ 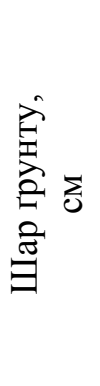 } & \multicolumn{6}{|c|}{ Структура посіву в сівозмінах, \% } \\
\hline & & 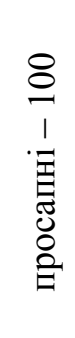 &  &  & 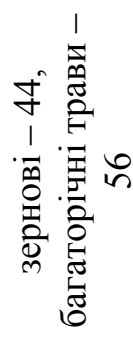 & 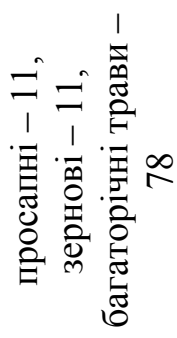 & 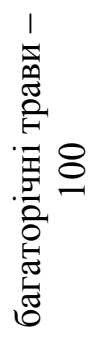 \\
\hline \multirow{2}{*}{ ГПВ } & $0-30$ & 72,2 & 73,1 & 76,6 & 78,6 & 77,9 & 79,1 \\
\hline & $0-50$ & 72,9 & 73,6 & 77,4 & 79,7 & 79,2 & 80,8 \\
\hline \multirow{2}{*}{ ВРК } & $0-30$ & 42,7 & 43,0 & 43,5 & 44,7 & 43,6 & 45,2 \\
\hline & $0-50$ & 43,2 & 43,4 & 43,9 & 44,9 & 44,0 & 45,6 \\
\hline \multirow{2}{*}{$\mathrm{BCB}$} & $0-30$ & 25,2 & 25,8 & 27,5 & 29,0 & 28,4 & 29,6 \\
\hline & $0-50$ & 26,0 & 26,4 & 27,8 & 29,4 & 28,9 & 30,0 \\
\hline \multirow{2}{*}{ МГВ } & $0-30$ & 6,0 & 6,2 & 6,6 & 6,9 & 7,2 & 7,1 \\
\hline & $0-50$ & 6,1 & 6,3 & 6,7 & 7,1 & 7,3 & 7,2 \\
\hline
\end{tabular}

2. Вологозапаси торфового трунту за відповідних водно-фізичних константах залежно від характеру довготривалого періоду використання, мм

\begin{tabular}{|c|c|c|c|c|c|c|}
\hline Структура посіву в сівозмінах, \% & $\begin{array}{c}\text { Шар грунту, } \\
\text { см }\end{array}$ & ПВ & ГПВ & ВРК & $\mathrm{BCB}$ & МГВ \\
\hline \multirow{2}{*}{ Просапні - 100} & $0-30$ & 230 & 166 & 98 & 58 & 14 \\
\hline & $0-50$ & 376 & 273 & 162 & 98 & 23 \\
\hline \multirow{2}{*}{$\begin{array}{c}\text { Просапні - } 56 \\
\text { Зернові - } 44\end{array}$} & $0-30$ & 240 & 176 & 103 & 62 & 15 \\
\hline & $0-50$ & 392 & 288 & 170 & 103 & 24 \\
\hline \multirow{2}{*}{$\begin{array}{c}\text { Просапні - } 12 \\
\text { Зернові }-44 \\
\text { Багаторічні трави }-44\end{array}$} & $0-30$ & 242 & 186 & 105 & 67 & 16 \\
\hline & $0-50$ & 413 & 319 & 180 & 115 & 28 \\
\hline \multirow{2}{*}{$\begin{array}{c}\text { Зернові }-44 \\
\text { Багаторічні трави }-56\end{array}$} & $0-30$ & 240 & 189 & 107 & 70 & 17 \\
\hline & $0-50$ & 407 & 324 & 182 & 120 & 29 \\
\hline \multirow{2}{*}{$\begin{array}{c}\text { Просапні - } 11 \\
\text { Зернові - } 11 \\
\text { Багаторічні трави }-78\end{array}$} & $0-30$ & 244 & 190 & 106 & 69 & 16 \\
\hline & $0-50$ & 407 & 321 & 178 & 117 & 28 \\
\hline \multirow{2}{*}{ Багаторічні трави - 100} & $0-30$ & 256 & 202 & 115 & 75 & 18 \\
\hline & $0-50$ & 433 & 348 & 196 & 128 & 31 \\
\hline
\end{tabular}

Висновок. Визначальним фактором у зміні водно-фізичних властивостей осушуваних торфових грунтів виступає характер їхнього сільськогосподарського використання. Регулювання співвідношення біологічних груп культур у сівозміні дає змогу спрямовувати еволюційний процес в оптимальних для сільськогосподарських культур режимах. Зменшення площ посіву під багаторічними травами, а також їхня повна заміна просапними культурами, призводить до істотного погіршення показників будови грунту, зниження його вологоємності та вмісту в ньому лег- кодоступної, оптимальної для засвоєння рослинами вологи, що $€$ негативним процесом $з$ точки зору екології.

Найбільш оптимальні параметри будови торфового грунту та водно-фізичні властивості формуються в разі впровадження монокультури багаторічних трав, трав'яно-просапних та зернотрав'яно-просапних сівозмін. Площа посіву трав у таких сівозмінах повинна становити не менше 56 \% від сівозмінної площі, просапних культур не більше $11 \%$. 


\section{БІБЛІОГРАФІЯ}

1. Белковский В. И. Повышение плодородия и рациональное использование торфяных почв / В. И. Белковский. - М. : Россельхозиздат, 1986. $126 \mathrm{c}$.

2. Гнида E. C. Опыт изучения влажности разрыва капиллярной связи торфяных почв / Е. С. Гнида // Мелиорация и водное хозяйство. 1982. - Вып. 54. - С. 61-65.

3. Мостовой М. Н. Характеристика торфяных почв Сарненской научно-исследовательской станции по освоению болот / М. Н. Мостовой, М. С. Портная // Осушение и освоение низинных болот полесской зоны. - К. : Урожай, 1965. C. $30-42$.

4. Писаренко В. М. Агроекологія : навч. посібник / В. М. Писаренко, П. В. Писаренко, В. В. Писаренко. - Полтава : [б. в.], 2008. - 256 с. 5. Роде A. A. Основы учения о почвенной влаге / А. А. Роде. - Л. : Гидрометеоролог, 1969. T. 2. $-289 \mathrm{c}$.

6. Рудько Г. I. Землеологія. Еколого-ресурсна безпека Землі : [монографія] / Г. І. Рудько, О. М. Адаменко / [за ред. Г. І. Рудька]. - К. : Академпрес, 2009. - 512 с. 